JURNAL NOMINAL / VOLUME VI NOMOR 2 / TAHUN 2017

\title{
FAKTOR YANG MEMPENGARUHI MANAJAMEN LABA PADA PERUSAHAAN PERBANKAN DI INDONESIA
}

\author{
Hafidza Ulfa A \\ Prodi Akuntansi Universitas Negeri Yogyakarta \\ havidzamada@gmail.com \\ Sukirno \\ Staf Pengajar Jurusan Pendidikan Akuntansi Universitas Negeri Yogyakarta
}

\begin{abstract}
Abstrak: Faktor yang Mempengaruhi Manajamen Laba pada Perusahaan Perbankan di Indonesia. Penelitian ini bertujuan untuk mngetahui: (1) Pengaruh Leverage terhadap Manajemen Laba; (2) Pengaruh Leverage terhadap Manajemen Laba dengan Dewan Komisaris Independen sebagai variabel moderasi; (3) Pengaruh Leverage terhadap Manajemen Laba dengan Kualitas Auditor sebagai variabel moderasi.Teknik pengumpulan data dilakukan dengan metode pengumpulan data dokumentasi. Pengumpulan data penelitian melalui analisis terhadap isi dari catatan atau dokumen perusahaan yang sesuai dengan data yang diperlukan. Data yang diperlukan dalam penelitian ini adalah data sekunder yang berasal dari laporan keuangan perusahaan sektor perbankan di BEI yang telah diaudit periode 2011-2015. Laporan keuangan tersebut diunduh dari situs www.idx.co.id. Teknik analisis yang digunakan adalah kuantitatif.Hasil penelitian menunjukkan bahwa: (1) Leverage berpengaruh negatif signifikan terhadap manajemen laba dengan koefisien regresi sebesar 0,802 dan $\mathrm{t}$ hitung $<\mathrm{t}$ tabel $(-4,544$ $<-1.97756)$; (2) Dewan Komisaris Independen memperkuat pengaruh Leverage terhadap Manajemen Laba dengan koefisien regresi sebesar 6,942 dan t hitung > t tabel (4,490 > 1,97756); (3) Kualitas Auditor memperkuat pengaruh Leverage terhadap Manajemen Laba dengan nilai koefisien regresi sebesar 0,251 dan t hitung $>\mathrm{t}$ tabel $(5,812>1,97756)$.

Kata Kunci: Leverage, Manajemen Laba, Corporate Governance, Dewan Komisaris Independen, Kualitas Audit.

Abstract: Factors Influencing Earnings Management on Banking Industries In Indonesia. The purposes of this research is to investigate: (1) The effect of Leverage on Earnings Management; (2) The effect of Leverage on Earning Management with Independent Board as moderating variable; (3) The effect of Leverage on Earnings Management with Auditor Quality as moderating variable. Data collected by the data collection methods of documentation. The collection of data empirically through an analysis of the contents of the records or documents that the company in and $F_{\text {statistic }}>F_{\text {table }} 8,362>3,90$. (3) The level of accordance with the necessary data. Data needed in this research is secondary data derived from company financial reports of the banking sector in BEI which have been audited period 2011-2015. These financial statements downloaded from the site www.idx.co.id. The analysis technique used is quantitative. The results showed that: (1) Leverage significant negative effect on earnings management with a regression coefficient of 0,802 and t statistic < t table $(-4.490<-1,97756)$; (2) Independent Commissioner Board of strengthening the influence of Leverage to Earnings Management with a regression coefficient of 6,942 and $t$ statistic > t table $(4,490>1,97756)$; (3) Strengthening the influence of the Auditor Quality Management Leverage to Profit with regression coefficient of 0,251 and $t$ statistic $>$ t table $(5,812>1,97756)$.
\end{abstract}

Keywords: Leverage, Earnings Management, Corporate Governance, Independent Commissioner Board, Auditor Quality. 
JURNAL NOMINAL / VOLUME VI NOMOR 2 / TAHUN 2017

\section{PENDAHULUAN}

Pengaruh globalisasi yang semakin canggih pada zaman sekarang mempengaruhi peningkatan pertumbuhan perekonomian di suatu negara yang akan didukung dengan berkembanganya dunia bisnis. Setiap perusahaan membutuhkan tambahan dana dari pihak luar perusahaan untuk kelangsungan hidup perusahaan tersebut. Dalam hal itu perusahaan diwajibkan menunjukkan kinerja yang baik dan sehat dengan memberikan informasi yang terdapat pada laporan keuangan perusahaan. Selain itu menghindari cara-cara menciptakan keuntungan sesaat dan lebih mengutamakan kelangsungan hidup perusahaan serta kepentingan para pemangku kepentingan dalam suatu perusahaan.

Penyampaian informasi laporan keuangan ini perlu dilakukan untuk memenuhi kebutuhan pihak-pihak eksternal maupun internal. Tujuan dari laporan keuangan adalah untuk menyampaikan informasi yang berguna untuk menilai kemampuan manajemen dalam menggunakan sumber daya perusahaan secara efektif guna mencapai sasaran utama perusahaan (Belkaoui, 2006).

Sampai sekarang laporan kuangan telah menjadi isu sentral sebagai sumber manipulasi dari informasi yang dapat merugikan pihak-pihak yang berkepentingan terhadap perusahaan. Scott (2006) didalam bukunya yang berjudul "Financial Accounting Theory" menyatakan bahwa pilihan kebijakan akuntansi yang dilakukan manajer untuk tujuan spesifik disebut dengan manajemen laba.

Manajemen laba digunakan untuk mempengaruhi tingkat pendapatan pada waktu tertentu untuk kepentingan manajemen maupun stakeholder. Belkaoui (2006) manajemen laba terjadi ketika para manajer menggunakan pertimbangan mereka dalam pelaporan keuangan dan struktur transaksi untuk mengubah laporan keuangan.

Manajemen laba yang dilakukan perusahaan muncul karena adanya hubungan agensi antara principal (pemegang saham) dan agent (manajer). Teori keagenan (agency theory) adalah teori yang menjelaskan bahwa hubungan agensi muncul ketika satu orang atau lebih (principal) mempekerjakan orang lain (agent) untuk memberikan suatu jasa dan kemudian mendelegasikan wewenang pengambilan keputusan kepada agen tersebut (Jensen dan Meckling, 1976).

Leverage merupakan tingkat sekuritas dengan utang digunakan dalam struktur modal sebuah perusahaan. Leverage adalah rasio yang digunakan untuk mengukur sejauh mana 


\section{JURNAL NOMINAL / VOLUME VI NOMOR 2 / TAHUN 2017}

perusahaan dibiayai oleh hutang
(Riyanto, 1995). Herawaty dan
Baridwan (2007) Percepatan jatuh
tempo, peningkatan tingkat bunga, dan
negosiasi ulang masa hutang merupakan
akibat yang dapat terjadi apabila
perusahaan melanggar kontrak hutang.
Hutang dapat meningkatkan manajemen
laba saat perusahaan ingin mengurangi
kemungkinan pelanggaran perjanjian
hutang dan meningkatkan posisi tawar
perusahaan selama negosiasi hutang (Klein, 2002).

Menurut Van Horn (1997) Financial Leverage merupakan penggunaan sumber dana yang memiliki beban tetap, dengan harapan akan memberikan tambahan keuntungan yang lebih besar dari pada beban tetap, sehingga keuntungan pemegang saham bertambah. Perusahaan yang memiliki hutang besar, memiliki kecenderungan melanggar perjanjian hutang jika dibandingkan dengan perusahaan yang memiliki hutang lebih kecil (Mardiyah, 2002).

\section{Menurut Winanda (2009)} corporate governance adalah sebuah konsep yang mengatur hubungan antara pemegang saham, dewan komisaris, dan dewan direksi pada sebuah perusahaan. Secara universal OECD (Organisation for Economic Co-operation and Development) memperkenalkan prinsipprinsip corporate governance antar lain adalah prinsip accountability, responsibility, transparency, fairness, dan independency. Oleh karena itu di negara-negara penerima dana lembaga ekonomi dan keuangan dunia seperti World Bank dan International Monetary Fund berkepentingan dalam penerapan corporate governance karena dianggap penerapan corporate governance termasuk bagian penting dalam sistem pasar yang efisien.

Sebuah survei yang dilakukan pada tahun 1999 oleh Price Waterhouse Coopers antara investor internasional di Asia, menunjukkan bahwa peringkat Indonesia adalah salah satu yang terburuk dalam standar audit dan kepatuhan, akuntabilitas kepada pemegang saham, standar pengungkapan dan transparansi (FCGI, 2006).

Populasi perusahaan yang digunakan dalam penelitian ini adalah perusahaan Perbankan yang terdaftar di Bursa Efek Indonesia (BEI). Hal ini dikarenakan terdapat perbedaan karakteristik antara perusahaan pada industri perbankan dan perusahaan industri lainnya. Dalam industri perbankan terdapat regulasi dan kriteria tertentu dari Bank Sentral yang harus dipenuhi. Adanya regulasi dari Bank Sentral dapat mendorong manajer melakukan manajemen laba, supaya perusahaan mereka dapat memenuhi kriteria yang disyaratkan. Berdasarkan 
JURNAL NOMINAL / VOLUME VI NOMOR 2 / TAHUN 2017

uraian latar belakang masalah di atas, maka topik penelitian ini berjudul "PENGARUH LEVERAGE TERHADAP MANAJEMEN LABA DENGAN CORPORATE GOVERNANCE SEBAGAI VARIABEL MODERASI PADA PERUSAHAAN PERBANKAN YANG TERDAFTAR DI BEI".

\section{METODE PENELITIAN}

Teknik analisis data dengan analisis regresi linier sederhana, regresi sederhana didasarkan pada hubungan fungsional ataupun kausal satu variabel independen dengan satu variabel dependen. Analisis ini digunakan untuk menguji hipotesis satu (H1). Analisis Moderated Regression Analysis (MRA).

Analisis MRA digunakan untuk mengetahui apakah variabel moderating akan memperkuat atau memperlemah hubungan antar variabel independen dan variabel dependen. Analisis ini digunakan untuk menguji hipotesis dua (H2) dan hipotesis tiga (H3). Berikut ini formula yang digunakan untuk menentukan nilai variabel penelitian.

Model Modifikasi Jones

Total accruals dengan menggunakan model Jones yang dimodifikasi.

$$
\mathrm{TAC}=\mathrm{NI}_{\mathrm{it}}-\mathrm{CF}_{\mathrm{it}}
$$

Dimana,

TAC $=$ Total accruals
NI_it = laba bersih (net income) perusahaan i pada periode $\mathrm{t}$ $\mathrm{CF}_{\mathrm{it}}=$ arus kas operasi (cash flow of operation) perusahaan i pada periode $\mathrm{t}$

Total accruals yang diestimasi dengan persamaan regresi OLS (Ordinary Least Square) adalah:

$$
\mathrm{TAC}_{\mathrm{t}} / \mathrm{TA}_{\mathrm{t}-1}=(\beta)_{1} \quad\left(1 / \mathrm{TA}_{\mathrm{t}-1}\right)+
$$

$(\beta)_{2}\left(\Delta \mathrm{REVt} / \mathrm{TA}_{\mathrm{t}-1}\right)+(\beta)_{3}\left(\mathrm{PPE}_{\mathrm{t}} /\right.$ $\left.\mathrm{TA}_{\mathrm{t}-1}\right)+\mathrm{e}$

Dimana,

$\mathrm{TAC}_{\mathrm{t}}=$ total accruals dalam periode $\mathrm{t}$ $\mathrm{TA}_{\mathrm{t}-1}=$ total aset periode $\mathrm{t}-1$

$(\Delta) \mathrm{REVt}=$ perubahan pendapatan dalam periode $\mathrm{t}$

$\mathrm{PPE}_{\mathrm{t}}=$ property, plan, and equipment periode $\mathrm{t}$

$(\beta)_{1},(\beta)_{2},(\beta)_{3}=$ koefisiensi regresi

$\mathrm{e}=$ error term $($ Galat $)$

Non Accruals Diskretioner

$$
\operatorname{NDTAC}_{\mathrm{t}}=(\beta)_{1}\left(1 / \mathrm{TA}_{\mathrm{t}-1}\right)+
$$

$(\beta)_{2}\left[\left(\Delta \mathrm{REV}_{\mathrm{t}}-\Delta \mathrm{REC}_{\mathrm{t}}\right) /\right.$

$\left.\mathrm{TA}_{\mathrm{t}-1}\right]+(\beta)_{3}\left(\mathrm{PPE}_{\mathrm{t}} / \mathrm{TA}_{\mathrm{t}-1}\right)+\mathrm{e}$

Dimana,

NDTAC $_{t}=$ non akrual diskresioner pada tahun $\mathrm{t}$

$\mathrm{TA}_{\mathrm{t}-1}=$ total aset periode $\mathrm{t}-1$

$(\Delta)$ REVt = perubahan pendapatan dalam periode $\mathrm{t}$ 


\section{JURNAL NOMINAL / VOLUME VI NOMOR 2 / TAHUN 2017}

$(\Delta) \mathrm{REC}_{\mathrm{t}}=$ perubahan piutang usaha dalam periode $\mathrm{t}$

$\mathrm{PPE}_{\mathrm{t}}=$ property, plan, and equipment periode $\mathrm{t}$

$(\beta)_{1},(\beta)_{2},(\beta)_{3}=$ fitted coefficient yang diperoleh dari hasil regresi pada perhitungan total akrual

$\mathrm{e}=\operatorname{error}$ term $($ Galat $)$

Diskresioner Total Akrual

$$
\mathrm{DTAC}_{\mathrm{t}}=\mathrm{TAC}_{\mathrm{t}} / \mathrm{TA}_{\mathrm{t}-1}-\mathrm{NDTAC}_{\mathrm{t}}
$$

Dimana,

DTAC $_{\mathrm{t}}=$ diskresioner total akrual tahun $\mathrm{t}$

$\mathrm{TAC}_{\mathrm{t}}=$ total accruals tahun $\mathrm{t}$

$\mathrm{TA}_{\mathrm{t}-1}=$ total aset periode $\mathrm{t}-1$

NDTAC $_{\mathrm{t}}=$ non akrual diskresioner pada tahun $t$

Variabel Independen (Bebas)

Leverage

$$
\text { Leverage }=\mathrm{TLt} / \mathrm{TAt}
$$

Dimana

TL : Total hutang pada periode $\mathrm{ke}-\mathrm{t}$

TA : Total aset pada periode $\mathrm{ke}-\mathrm{t}$

Variabel Moderasi

Dewan Komisaris Indepeden (DKI)

$\frac{\text { Jumlah Komisaris Independen }}{\text { Jumlah Dewan Komisaris }} \times 100 \%$

Kualitas Auditor (KA)
Untuk mengukur kualitas auditor digunakan Ukuran Kantor Akuntan Publik (KAP). Jika perusahaan diaudit oleh KAP besar pada saat penelitian ini yaitu KAP Big 4 maka kualitas auditnya tinggi dan jika diaudit oleh KAP Non Big 4 (KAP kecil) maka kualitas auditnya rendah.

HASIL PENELITIAN DAN PEMBAHASAN

Pada variabel dependen berupa manajemen laba memiliki nilai minimum sebesar -1.806, nilai maksimum 0,29, nilai mean $-0,044$, dan nilai standar deviasi 0,22 . Perusahaan yang memiliki nilai manajemen laba terendah adalah PT Bank Pembangunan Daerah Banten Tbk pada tahun 2013. Sedangkan perusahaan yang memiliki nilai manajemen laba tertinggi PT Bank QNB Indonesia Tbk pada tahun 2011.

Untuk variabel leverage memiliki nilai minimum sebesar 0.001 , nilai maksimum 0.94, nilai mean 0.87, dan nilai standar deviasi 0.08 . Perusahaan yang memiliki leverage terendah adalah PT Bank Nusantara Parahyangan Tbk pada tahun 2015. Sedangkan perusahaan memiliki leverage tertinggi adalah PT Bank QNB Indonesia Tbk pada tahun 2015.

Sedangkan untuk variabel moderasi pertama berupa kepemilikan institusional memiliki nilai minimum 


\section{JURNAL NOMINAL / VOLUME VI NOMOR 2 / TAHUN 2017}

sebesar 0,40 , nilai maksimum 0.80 , nilai mean 0.58 , dan nilai standar deviasi 0.09 . Perusahaan yang memiliki Dewan Komisaris Independen terendah adalah PT Bank Mayapada Internasional Tbk. Sedangkan perusahaan memiliki Dewan Komisaris Independen tertinggi adalah PT Bank Woori Saudara Indonesia Tbk.

Sedangkan untuk variabel moderasi kedua berupa kualitas auditor, dimana perusahaan yang memiliki kualitas auditor KAP non Big 4 adalah PT Bank Capital Indonesia Tbk, PT Bank Nusantara Parahyangan Tbk, PT Bank Tabungan Negara Tbk, PT Bank JTrust Indonesia Tbk, PT Bank Sinarmas Tbk, PT Bank Artha Graha Internasional Tbk, dan PT Bank Mayapada Internasional. Sedangkan perusahaan memiliki kualitas audit KAP Big 4 adalah PT Bank Rakyat Indonesia Agroniaga Tbk, PT Bank MNC Internasional Tbk, PT Bank Central Asia Tbk, PT Bank Bukopin Tbk, PT Bank Negara Indonesia Tbk, PT Bank Rakyat Indonesia Tbk, PT Bank Danamon Tbk, PT Bank Pembangunan Daerah Jawa Barat dan Banten Tbk, PT Bank QNB Indonesia Tbk, PT Bank Mandiri Tbk, PT Bank Bumi Artha Tbk, PT Bank CIMB Niaga Tbk, PT Bank Permata Tbk, PT Bank Tabungan Pensiunan Nasional Tbk, PT Bank Victoria Internasional Tbk, PT Bank Windu Kentjana Internasional Tbk, PT Bank
Mega Tbk, PT OCBC NISP Tbk, PT Bank Pan Indonesia Tbk, dan PT Bank Woori Saudara Indonesia Tbk.

Uji Hipotesis

H1: Leverage berpengaruh terhadap Manajemen Laba pada perusahaan perbankan yang terdaftar di BEI.

H2: Dewan Komisaris Independen memperkuat pengaruh Leverage terhadap Manajemen Laba pada perusahaan perbankan yang terdaftar di BEI.

H3: Kualitas Audit memperkuat pengaruh Leverage terhadap Manajemen Laba pada perusahaan perbankan yang terdaftar di BEI.

Tabel 5. Ringkasan Hasil Analisis Regresi Linier Sederhana - Model Regresi I

\begin{tabular}{lcllllcc}
\hline $\begin{array}{l}\text { Const } \\
\text { anta }\end{array}$ & $\begin{array}{c}\text { Unstand } \\
\text { ardized } \\
\text { Coeficie } \\
\text { nt }\end{array}$ & $\mathbf{R}$ & $\mathbf{R}^{2}$ & $\begin{array}{c}\mathbf{F}- \\
\text { stati } \\
\text { stik }\end{array}$ & $\begin{array}{c}\text { Si } \\
\text { g. }\end{array}$ & $\begin{array}{c}\text { t- } \\
\text { stati } \\
\text { stik }\end{array}$ & $\begin{array}{c}\text { Si } \\
\text { g.t }\end{array}$ \\
\hline $\mathbf{0 , 8 0 2}$ & $-0,971$ & 0.3 & 0.1 & 20,6 & 0,0 & - & 0,0 \\
& & 61 & 30 & 54 & 00 & 4,54 & 00 \\
& & & & & & 4 & \\
\hline
\end{tabular}

Berdasarkan tabel tersebut dapat disimpulkan bahwa Leverage berpengaruh negatif terhadap Manajemen Laba. 


\section{JURNAL NOMINAL / VOLUME VI NOMOR 2 / TAHUN 2017}

Tabel 6. Ringkasan Hasil Analisis Regresi Linier Berganda - Model Regresi II

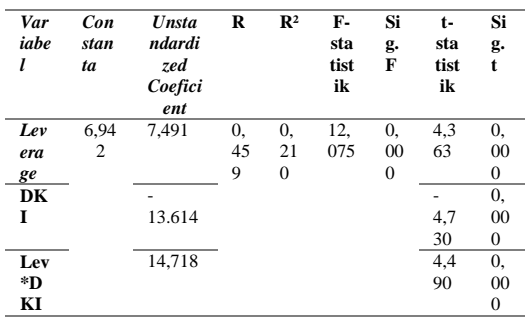

Berdasarkan tabel tersebut dapat disimpulkan bahwa Dewan Komisaris Independen memperkuat pengaruh Leverage terhadap Manajemen Laba.

Tabel 7. Ringkasan Hasil Analisis Regresi Linier Berganda - Model Regresi III

\begin{tabular}{|c|c|c|c|c|c|c|c|c|}
\hline $\begin{array}{l}\text { Var } \\
\text { iabe } \\
l\end{array}$ & $\begin{array}{l}\text { Con } \\
\text { stan } \\
\text { ta }\end{array}$ & $\begin{array}{c}\text { Unsta } \\
\text { ndardi } \\
\text { zed } \\
\text { Coefici } \\
\text { ent }\end{array}$ & $\mathbf{R}$ & $\mathbf{R}^{2}$ & $\begin{array}{c}\text { F- } \\
\text { stat } \\
\text { isti } \\
k\end{array}$ & $\begin{array}{l}\mathrm{Si} \\
\text { g. } \\
\text { F }\end{array}$ & $\begin{array}{c}\mathbf{t}- \\
\text { stat } \\
\text { isti } \\
\mathbf{k}\end{array}$ & $\begin{array}{l}\text { Si } \\
\text { g. } \\
\text { t }\end{array}$ \\
\hline $\begin{array}{l}\text { Lev } \\
\text { era } \\
\text { ge }\end{array}$ & $\begin{array}{c}0,25 \\
1\end{array}$ & 0,285 & 3 & $\begin{array}{l}0, \\
21 \\
5\end{array}$ & 391 & $\begin{array}{l}0, \\
00 \\
0\end{array}$ & $\begin{array}{l}\overline{1,3} \\
08\end{array}$ & $\begin{array}{l}0, \\
19 \\
3\end{array}$ \\
\hline KA & & -2.441 & & & & & $\begin{array}{l}- \\
5,9 \\
40\end{array}$ & $\begin{array}{l}0, \\
00 \\
0\end{array}$ \\
\hline $\begin{array}{l}\text { Lev } \\
\text { * }^{\mathbf{K}} \\
\mathbf{A}\end{array}$ & & 2,741 & & & & & $\begin{array}{l}5,8 \\
12\end{array}$ & $\begin{array}{l}0, \\
00\end{array}$ \\
\hline
\end{tabular}

Berdasarkan tabel tersebut dapat disimpulkan bahwa Kualitas Auditor memperkuat pengaruh Leverage terhadap Manajemen Laba.

a) Pegaruh Leverage terhadap Manajemen Laba

Hasil uji hipotesis pertama menghasilkan nilai koefisien regresi sebesar -0,971 yang berarti negatif yaitu semakin tinggi Leverage maka Manajemen Laba akan semakin turun. Jika dilihat dari nilai $\mathrm{R}^{2}$ sebesar 0,130 menunjukkan presentase Leverage mempengaruhi Manajemen Laba sebesar $13 \%$ sedangkan $82 \%$ dipengaruhi oleh faktor lain di luar penelitian. Dari tabel analysis of variance (ANOVA) dapat diketahui bahwa nilai signifikansi sebesar 0,000 yang berarti dengan nilai $t$ hitung $>t$ tabel. Berdasarkan hasil regresi di atas dapat disimpulkan bahwa $\mathrm{H} 1$ dapat didukung artinya Leverage berpengaruh negatif terhadap Manajemen Laba. Hasil tersebut sesuai dengan penelitian sebelumnya Perdana (2012), dan Mahiswari dan Nugroho (2014). Penelitian ini memiliki hasil yang bertentangan dengan penelitian Gumanti dan Singgih (2006) dan Trisnawati (2009), dimana hasil penelitian mereka menyatakan bahwa kenaikan Leverage ataupun tingkat Leverage yang tinggi tidak berpegaruh terhadap Manajemen Laba.

b) Pengaruh Leverage terhadap Manajemen Laba dengan Dewan Komisaris Independen sebagai variabel moderasi

Hasil uji hipotesis kedua dalam penelitian ini dapat didukung. Hal ini dibuktikan dengan sesudah adanya interaksi Lev*DKI nilai signifikansi sebesar 0,000 dan nilai unstandrized coefficients 14,718 . Jika dilihat dari nilai $\mathrm{R}^{2} \quad$ sebesar 0,210 menunjukkan presentase Lev*DKI sebesar $21 \%$ sedangkan $79 \%$ dipengaruhi oleh faktor 


\section{JURNAL NOMINAL / VOLUME VI NOMOR 2 / TAHUN 2017}

lain di luar penelitian. Nilai F statistik sebesar 12,075 dan tingkat signifikansi F. sebesar 0,000. Dalam penelitian ini Dewan Komisaris Indepeden terbukti memperkuat pengaruh Leverage terhadap Manajemen Laba. Hasil tersebut sesuai dengan penelitian sebelumnya Nasution dan Setiawan (2007) dan Wedari (2004). Penelitian ini memiliki hasil yang bertentangan dengan penelitian Veronica dan Utama (2005), dan Boediono (2005) dimana hasil penelitian mereka menyatakan bahwa proporsi dewan komisaris independen tidak berpengaruh terhadap tindak manajemen laba yang dilakukan suatu perusahaan.

c) Pengaruh Leverage terhadap Manajemen Laba dengan Kualitas Auditor sebagai variabel moderasi

Hasil uji hipotesis ketiga dalam penelitian ini dapat didukung. Hal ini dibuktikan dengan sesudah adanya interaksi Lev*KA nilai signifikansi sebesar 0,000 dan nilai unstandrized coefficients 2,741. Jika dilihat dari $\mathrm{R}^{2}$ sebesar 0,215 menunjukkan presentase Lev*KA sebesar 21,5\% sedangkan $78,5 \%$ dipengaruhi oleh faktor lain di luar penelitian. Nilai F statistik sebesar 12,391 dan tingkat signifikansi F sebesar 0,000. Dalam penelitian ini Kualitas Auditor terbukti memperkuat pengaruh Leverage terhadap Manajemen Laba. Hasil tersebut sesuai dengan penelitian sebelumnya Naftalia (2013) dan Becker dkk (1998). Penelitian ini memiliki hasil yang bertentangan dengan Kurniawati (2009) dan Wiyardi dan Sebrina (2013) penelitian dimana hasil penelitian mereka menyatakan bahwa kualitas auditor suatu perusahaan tidak mempengaruhi manajemen laba.

\section{SIMPULAN DAN SARAN}

Berdasarkan hasil penelitian yang telah diuraikan sebelumnya dapat ditarik kesimpulan Leverage berpengaruh negatif terhadap Manajemen Laba pada perusahaan perbankan yang terdaftar di BEI tahun 2011-2015. Hal ini ditunjukkan dengan nilai signifikasi sebesar 0,000 lebih kecil dari 0,05 berarti terdapat pengaruh signifikan serta nilai koefisien regresi sebesar 0,802, F hitung $>$ F tabel $(20,654>2,67)$ dan $\mathrm{t}$ hitung $<\mathrm{t}$ tabel $(-4,544<-1.97756)$. Dewan Komisaris Independen memperkuat pengaruh Leverage terhadap Manajemen Laba pada perusahaan perbankan yang terdaftar di BEI tahun 2011-2015. Hal ini ditunjukkan dengan nilai signifikasi 0,000 lebih kecil dari 0,05 berarti terdapat pengaruh positif signifikan serta nilai koefisien regresi sebesar 6,942, F hitung > F tabel $(12,075>2,67)$ dan $t$ hitung > t tabel $(4,490>1,97756)$. Kualitas Auditor memperkuat pengaruh Leverage terhadap Manajemen Laba pada perusahaan perbankan yang 


\section{JURNAL NOMINAL / VOLUME VI NOMOR 2 / TAHUN 2017}

terdaftar di BEI tahun 2011-2015. Hal ini

ditunjukkan dengan nilai signifikasi 0,000 lebih kecil dari 0,05 berarti terdapat pengaruh positif signifikan serta nilai koefisien regresi sebesar 0,251, F hitung $>\mathrm{F}$ tabel $(12,391>2,67)$ dan $\mathrm{t}$ hitung $>\mathrm{t}$ tabel $(5,812>1,97756)$.

Saran yang bisa disampaikan dari hasil penelitian yaitu: menambah periode pengamatan agar pengaruh leverage terhadap manajemen laba, serta menambah indeks atau proksi lain yang terdiri dalam corporate governance dapat lebih dirasakan dalam mendeteksi manajemen laba. Menambahkan sampel dan jenis perusahaan yang lebih besar lagi dan bukan hanya terdiri dari perusahaan perbankan dimana tidak dapat menggambarkan seluruh jenis perusahaan yang ada di Indonesia tentang manajemen laba suatu perusahaan.

Menambah variabel independen (bebas) lainnya yang dapat mempengaruhi manajemen laba seperti asimetri informasi dalam penelitian mengenai manajemen laba sudah banyak dibahas, tinggal mengkaitkan dengan variabel moderasi dari corporate governance itu sendiri seperti kepemilikan manajerial, dan kepemilikan institusional. Sebaiknya dalam mengukur Corporate Governance menggunakan nilai yang sudah di akumulatif secara keseluruhan, sehingga mengetahui skor Corporate Governance secara keseluruhan dalam penelitian misalnya, indeks yang diterbitkan oleh Indonesian Institute adalah mahasiswa yang telah lulus atau sedang menempuh mata kuliah Akuntansi Manajemen atau Sistem Pengendalian Manajemen atau Penganggaran. of Corporate Governance (IICG) yaitu Corporate Governance Perception Indeks (CGPI) yang diterbitkan dalam media massa tiap tahunnya. Karakteristik yang dapat ditambah dalam Dewan Komisaris Independen dan Kualitas Auditot misalnya, latar belakang pendidikan, pengalaman komisaris independen, dan auditor. Sebelum melakukan penelitian, Peneliti selanjutnya disarankan untuk memastikan kelengkapan data yang akan digunakan dalam penelitian sehingga tidak menemui kendala pada saat penelitian.

\section{DAFTAR PUSTAKA}

Becker, Defond, Jiambalvo, dan Subramanyam. (1998). "The Effect of Audit Quality On Earnings Management”. Contemporary Accounting Research. P:1-24.

Belkaoui, A. Riahi. (2006). Teori Akuntansi. Jakarta: Salemba Empat.

Boediono. (2005). "Kualitas Laba: Studi Pengaruh Mekanisme Corporate Governance dan Dampak Manajemen Laba dengan Menggunakan Analisis 


\section{JURNAL NOMINAL / VOLUME VI NOMOR 2 / TAHUN 2017}

Jalur". Simposium. Nasional Akuntansi VIII. Solo.

Dechow, P.M., R.G. Sloan, dan A.P. Sweeney. (1995). "Detecting Earning Management". The Accounting Review. Vol. 70 No. 2. P:193-225.

FCGI (Forum for Corporate Governance in Indonesia). (2006). How is the Indonesian Corporate Govenance in Reality. Artikel. Diakses tanggal 5 November 2016, dari www.fcgi.com.

Gumanti, dan Singgih. (2006). "Earning Management antar Industri dan Faktor-faktor Pembatasnya pada Perusahaan Publik di Bursa Efek indonesia". Jurnal Akuntansi dan Bisnis, Vol. 6 No. 2. Hal 181-192.

Herawaty, dan Baridwan. (2007). "Manajemen Laba dan Perusahaan yang Melanggar Hutang". Simposium. Nasional Akuntansi X.

Jensen, Michael C. dan W.H. Meckling. (1976). "Theory of The Firm: Managerial Behavior, Agency Cost and Ownership Structure". Journal of Financial Economics. Vol. 3. P:305-360.

Klein, A. (2002). "Audit Committee, Board of Director Characteristics, and Earnings Management". Journal of Accounting and Economics. Vol. 33. P:375-400.

Kurniawati, F. (2009). "Pengaruh Asimetri Informasi Dan Kualitas Auditor Terhadap Manajemen Laba Pada Perusahaan Yang Bergerak Di Sektor Keuangan Yang Terdatar Di BEI". Skripsi. Universitas Negeri Solo. Dipublikasikan.
Mardiyah, Aida. (2002). "Pengaruh Informasi Asimetri dan Disclosure terhadap Cost of Capital", Jurnal Riset Akuntansi Indonesia, Vol.5 No.2. Hal 229256.

Mahiswari, dan Nugroho. (2014). "Pengaruh Mekanisme Corporate Governance, Ukuran Perusahaan dan Leverage Terhadap Manajemen Laba dan Kinerja Keuangan". Jurnal Ekonomi dan Bisnis. Vol. 17. No.1.

Nasution, M dan Setiawan. (2007). "Pengaruh Corporate Governance terhadap Manajemen Laba di Industri Perbankan Indonesia". Simposium. Nasional Akuntansi X. Makassar.

Naftalia. (2013). "Pengaruh Leverage Terhadap Manajemen Laba Dengan Corporate Governance Sebagai Variabel Pemoderasi". Skripsi. Universitas Diponegoro. Dipublikasikan.

OECD (Economic Co-Operation and Development). (2004). Principles of Corporate Governance. Artikel. Diakses tanggal 5 November 2016, dari www.oecd.org.

Perdana, Riko. (2012). "Pengaruh Firm Size, Leverage, Good Corporate Governance, dan Profitabilitas Terhadap Earning Management”. Skripsi. Universitas Diponegoro. Dipublikasikan.

Riyanto. (1995). Dasar-dasar Pembelanjaan Perusahaan. Edisi keempat. Yogyakarta: Yayasan Penerbit Gajah Mada. 
JURNAL NOMINAL / VOLUME VI NOMOR 2 / TAHUN 2017

Scott, R. William. (2006). Financial Accounting Theory $4^{\text {th }}$ Edition. New Jersey: Prentice-Hall.

Trisnawati, R. (2009). "Pengaruh Leverage Terhadap Manajemen Laba Dengan Variabel Pemoderasi Arus Kas Bebas Pada Perusahaan Manufaktur Publik Yang Terdaftar Di Bursa Efek Indonesia”. Skripsi. Universitas Negeri Solo. Dipublikasikan.

Van Horne, dan James C. (1997). Prinsip-prinsip Manajemen Keuangan, Jakarta: Salemba Empat.

Veronica, dan Utama. (2005) "Pengaruh Struktur Kepemilikan, Ukuran Perusahaan, dan Praktek Corporate Governance terhadap Pengelolaan Laba (Earning Management )". Simposium. Nasional Akuntansi VIII. Solo.

Wedari. (2004). "Analisis Pengaruh Proporsi Dewan Komisaris dan Keberadaan Komite Audit terhadap Aktivitas Manajamen Laba". Simposium. Nasional Akuntansi VII. Denpasar.

Winanda, A. Putri dan Ardiyanto, M. Didik. (2009). "Analisis Pengaruh Penerapan Good Corporate Governance Dan Struktur Kepemilikan Terhadap Kinerja Perusahaan”. Skripsi. Universitas Diponegoro. Dipublikasikan.

Wiyardi, A dan Sebrina. (2013). "Pengaruh Asimetri Informasi, Kualitas Audit, dan Struktur Kepemilikan Terhadap Manajemen Laba”. WRA. Vol. 1 No. 2. 